\title{
Pengembangan Media Interaktif Berbasis E-Book Melalui Pendekatan SAVI Pada Pembelajaran IPA Kelas IV Sekolah Dasar
}

\author{
Mitia Arizka Wardani, Aiman Faiz, Dewi Yuningsih
}

Universitas Muhammadiyah Cirebon

mitiaarizka@gmail.com

\author{
Article History \\ received 25/7/2021 \\ revised $23 / 10 / 2021$ \\ accepted 6/11/2021
}

\begin{abstract}
The lack of active participation of students and the difficulty of teachers in conveying the concept of abstract science subject matter is caused by several factors, including not yet applying the use of media in the learning process so that the material presented is abstract. The purpose of this research is to develop and validate products in the form of interactive learning media with ebook concepts through the SAVI approach to science learning in grade IV. This study adopted the development concept developed by Borg and Gall which was modified by Sugiyono from stage one to stage six. The subjects in this study were fourth grade students of SDN Jatipamor I. The data collection instrument used in this study was a Likert scale questionnaire with qualitative descriptive data analysis techniques and quantitative descriptive data. The results of the expert validation research show that ebook-based interactive media through the SAVI approach in class IV science learning can be said to be very feasible by experts according to the feasibility indicators of media and materials. As for the small-scale trial stage, the developed media also received a very good response from teachers and students. Thus the development of ebook-based interactive learning media is expected to be an alternative learning so that the concepts in science material can be conveyed properly

Keywords: Interactive media, ebook based, SAVI approach
\end{abstract}

\begin{abstract}
Abstrak
Kurangnya partisipatif aktif siswa dan kesulitan guru dalam menyampaikan konsep materi pelajaran IPA yang bersifat abstrak disebabkan oleh beberapa faktor, diantaranya belum teraplikasinya penggunaan media dalam proses pembelajaran sehingga materi yang disampaikan bersifat abstrak. Tujuan penelitian ini untuk mengembangkan dan memvalidasi produk berbentuk media pembelajaran yang interaktif dengan konsep ebook melalui pendekatan SAVI pada pembelajaran IPA di kelas IV. Penelitian ini mengadopsi konsep pengembangan yang dikembangkan oleh Borg and Gall yang dimodifikasi oleh Sugiyono dari tahap satu sampai tahap enam. Subjek dalam penelitian ini adalah siswa kelas IV SDN Jatipamor I. Adapun instrumen pengumpulan data yang digunakan dalam penelitian ini adalah angket kuesioner skala likert dengan teknik analisis data deskriptif kualitatif dan deskriptif kuantitatif. Hasil penelitian validasi ahli menunjukkan bahwa media interaktif berbasis ebook melalui pendekatan SAVI pada pembelajaran IPA kelas IV dapat dikatakan sangat layak oleh pakar sesuai dengan indikator kelayakan media dan materi. Adapun pada tahap uji coba skala kecil, media yang dikembangkan juga memperoleh respon yang sangat baik dari guru maupun siswa. Dengan demikian pengembangan media pembelajaran interaktif berbasis ebook diharapkan menjadi salah satu alternatif pembelajaran agar konsep dalam materi IPA bisa tersampaikan dengan baik
\end{abstract}

Kata kunci: Media interaktif, berbasis ebook, pendekatan SAVI. 


\section{PENDAHULUAN}

Kemajuan teknologi dewasa ini memberikan efek perubahan yang sangat signifikan bagi tatanan kehidupan manusia, tak terkecuali dalam bidang pendidikan (Faiz et al., 2020: 52). Memperkenalkan teknologi kepada siswa sedini mungkin merupakan tugas dari pendidikan, agar nantinya lulusan yang dihasilkan dapat memenuhi kebutuhan dunia kerja pada saat ini (Yaumi, 2018:14). Pada saat ini sasaran pendidikan adalah siswa generasi alpha. Generasi alpha adalah generasi yang sangat erat dengan aktivitas yang berlandaskan teknologi. Bahkan generasi ini juga disebut generasi yang memiliki ketergantungan tinggi terhadap peran teknologi. Intensitas generasi ini yang sudah tak asing lagi dengan tampilan layar sentuh, membuat mereka terampil dalam memperoleh informasi dalam segala hal (Istiqomah dan Kusuma, 2019:596).

Maka dari itu, dengan ketergantungan yang tinggi perlu diberikan sentuhan edukatif. Media pembelajaran terintegrasi teknologi diyakini menjadi salah satu alternatif yang dapat digunakan oleh guru dalam memfasilitasi siswa. Pembelajaran yang dapat dikembangkan dan menjadi kebutuhan dalam media pembelajaran salah satunya materi IImu Pengetahuan Alam (IPA). IPA merupakan subjek materi yang mampu memberikan kesempatan bagi siswa secara nyata dan memberikan imajinasi dalam memanfaatkan alat-alat maupun media pembelajaran yang tersedia di lingkungan sekitarnya, dengan harapan dalam pembelajaran IPA siswa bisa memberikan pengetahuan dan meneliti fenomena dalam kehidupan seharihari (Wedyawati dan Lisa, 2019:30). Untuk itu, guru dalam merancang pembelajaran IPA di SD seharusnya mempertimbangkan keterlibatan berbagai alat indera yang dimiliki oleh siswa dan juga perkembangan ilmu pengetahuan dan teknologi, se siswa (Putri, dkk, 2017:362). Oleh karena itu, pengembangan media dalam pembelajaran IPA diperlukan untuk memberikan sesuatu yang baru agar pembelajaran dapat berjalan optimal terutama dalam keadaan pandemi saat ini.

Berdasarkan pada studi pendahuluan diketahui bahwa proses pembelajaran di SDN Jatipamor 1 dilaksanakan dengan sistem pembelajaran jarak jauh (online). Hal ini semakin menunjukkan bahwa hadirnya media pembelajaran semakin diperlukan untuk memfasilitasi siswa belajar secara mandiri dirumah. Namun faktanya, penggunaan media masih kurang bervariatif dan belum memanfaatkan media pembelajaran berbasis teknologi yang seharusnya diterapkan pada generasi saat ini. Pelaksanaan pembelajaran IPA di kelas IV masih mengandalkan buku cetak sebagai media pembelajaran utamanya. Buku cetak yang digunakan oleh guru sebagai media pembelajaran hanya berisi uraian materi, beberapa ilustrasi gambar dan latihan soal dengan bentuk soal yang kurang bervariasi, sehingga media pembelajaran tersebut kurang menarik dan pesan yang disampaikan tidak mencapai tujuan pembelajadan karena visualisasi konsep materi yang bersifat abstrak seperti materi bentuk dan perubahan energi masih bias. Idealnya merujuk pada teori belajar kognitif Piaget bahwa siswa kelas IV berada pada tahap operasional konkret yaitu tahap dimana siswa sudah dapat melakukan penalaran secara logis untuk hal-hal yang bersifat konkret, namun belum mampu untuk menalar hal-hal yang bersifat abstrak, sehingga diperlukan jembatan yang dapat digunakan untuk menghubungkan dan menyederhanakan materi yang kompleks agar lebih jelas (Batubara, 2020:13).

Di sisi lain, dampak yang terjadi apabila siswa kurang memahami atau sulit memahami konsep pembelajaran IPA adalah kurangnya partisipatif aktif siswa. Penggunaan media pembelajaran yang belum bervariasi dan belum bisa memfasilitasi berbagai jenis belajar siswapun mengakibatkan pembelajaran menjadi pasif sebagaimana penelitian Nefrita (2019) yang mengungkapkan bahwa penggunaan media dalam pembelajaran mampu meningkatkan keaktifan siswa dan membuat siswa menjadi lebih tertarik, termotivasi untuk menguasai materi dan lebih percaya diri untuk mengikuti proses pembelajaran.

Dengan demikian, hadirnya media pembelajaran menjadi hal yang sangat penting dalam membantu siswa belajar secara mandiri, mengingat kondisi penyebaran pandemi covid-19 yang terus berubah-ubah mengakibatkan proses pendidikan yang harus dirubah menyesuaikan dengan keadaan baru (Faiz et al., 2021: 1774), sehingga proses pembelajaran harus tetap berlangsung meskipun dengan memanfaatkan media teknologi baik melalui e-learning, teleconfrence, WhatsApp dan berbagai media aplikasi lainnya (Faiz, 
2021: 131). Ketidakasingan siswa dalam memanfaatkan perangkat elektronik juga mendukung adanya sebuah inovasi media pembelajaran yang dapat membantu siswa untuk belajar di kelas maupun ketika mengulas kembali materi yang sudah dipelajari di rumah. Salah satu inovasi media pembelajaran yang terintegrasi dengan teknologi yang dapat digunakan adalah media interaktif berbasis ebook.

Media interaktif berbasis ebook merupakan media pembelajaran berbasis buku digital atau buku elektronik yang membuat penggunanya dapat melakukan interaksi bahkan berkomunikasi dua arah (Jannah, dkk, 2017:187). Ebook interaktif memungkinkan guru untuk menyajikan materi dalam bentuk yang lebih bervariasi dan mudah dipahami oleh siswa melalui berbagai komponen yang dapat diintegrasikan ke dalam ebook, seperti gambar, audio dan video pembelajaran, sehingga lebih menarik perhatian siswa dalam mengikuti pembelajaran, sehingga memberikan efek pada keberhasilan belajar siswa (Suryani dan Sukarmin, 2012:55). Hal tersebut didukung dengan pernyataan Ebied dan Rahman (Jannah, dkk, 2017:187) yang menyatakan bahwa siswa yang belajar dengan memanfaatkan media ebook interaktif, motivasi belajar dan prestasi akademiknya dapat meningkat, dibandingkan dengan siswa yang hanya belajar menggunakan buku teks saja.

Beberapa penelitian juga telah dilakukan dalam upaya mengembangkan ebook interaktif dan terbukti ebook memberikan efek yang positif dalam meningkatkan pengalaman belajar siswa (Yogiswara, 2019; Anggraini, 2018; Syafitri, 2020). Adapun pembeda penelitian ini dengan penelitian sebelumnya adalah; 1) Penulis menggunakan perangkat pembuat ebook yang berbeda dari penelitian sebelumnya; 2) penelitian ini difokuskan pada pengembangan media atau konten yang diintegrasikan ke dalam ebook interaktif; 3) Penulis menggabungkan ebook interaktif dengan unsur-unsur pendekatan SAVI (Somatik, Audio, Visual, dan Intelektual). Dengan demikian, pembeda dalam penelitian ini dengan yang lain adalah terletak pada pendekatannya.

Menurut Meier yang dikutip oleh Madang, dkk (2017:72) pendekatan SAVI adalah pendekatan yang mengkolaborasikan antara gerakan fisik, intelektual yang menggunakan seluruh indera yang dimiliki siswa selama pembelajaran. Pembelajaran dengan menggunakan media interaktif berbasis ebook yang digabungkan dengan unsur-unsur pendekatan SAVI mampu memberikan kemudahan baik bagi guru maupun siswa dalam menyampaikan dan memahami pembelajaran IPA. Ebook interaktif yang digabungkan dengan unsur-unsur pendekatan SAVI dapat memaksimalkan penggunaan indera yang dimiliki siswa, kemampuan intelektual siswa, serta dapat memfasilitasi kebutuhan gaya belajar siswa yang beragam, sehingga memberi kesempatan kepada seluruh siswa untuk memahami materi dengan lebih baik sebagaimana dikatakan Budiyanto (2013:46) bahwa pendekatan SAVI mampu mengatasi berbagai jenis gaya belajar siswa. Hal ini menunjukkan bahwa dengan perbedaan gaya belajar, siswa yang memiliki kecenderungan somatis, auditori, maupun visual dapat bersama-sama menyerap materi yang disajikan guru. Disamping itu, SAVI juga mampu mendorong siswa agar berpikir kritis dan kreatif dalam memecahkan masalah karena mendorong siswa lebih aktif sebagaina diungkapkan oleh Lukitawati (2014:45) yang menyebutkan bahwa dengan pendekatan SAVI memberikan stimulus agar siswa lebih aktif baik dalam tindakan, mendengatrkan melihat maupun mengamati proses pembelajaran secara kritis dan kreatif.

Berdasarkan uraian tersebut, maka tujuan penelitian ini untuk mengembangkan dan memvalidasi produk berbentuk media pembelajaran yang interaktif dengan konsep ebook melalui pendekatan SAVI pada pembelajaran IPA di kelas IV.

\section{METODE}

Penelitian ini adalah penelitian pengembangan, fokus dan tujuan penelitian ini adalah untuk menghasilkan produk media pembelajaran dan memvalidasi produk tersebut kepada para ahli. Meskipun tidak sampai uji coba secara luas, namun penelitian ini bisa menjadi dasar bagi para peneliti lain untuk digunakan sebagai landasan atau gagasan awal pengembangan media SAVI lainnya. Model penelitian dan pengembangan dalam penelitian ini menggunakan model Borg and Gall yang dimodifikasi oleh Sugiyono (2015:409) yang terdiri atas sepuluh langkah yaitu: 1) Tahap analisis potensi dan masalah, 2) Tahap 
pengumpulan infomasi, 3) Tahap desain produk, 4) Validasi desain, 5) Revisi desain, 6) Uji coba produk, 7) Revisi produk, 8) Uji coba pemakaian, 9) Revisi Produk, 10) Pembuatan Produk masal. Namun, pada penelitian ini penulis melakukan pembatasan penelitian yaitu hanya sampai pada tahap keenam, uji coba produk skala kecil. Penerapan langkah-langkah penelitian ini dilakukan dengan menyesuaiakan kebutuhan dan tujuan penelitian yaitu untuk mengetahui kelayakan produk yang dihasilkan meskipun masih dalam lingkup uji coba yang tidak luas. Lokasi penelitian dilaksanakan di SDN Jatipamor I Kecamatan Panyingkiran Kabupaten Majalengka. Subjek coba pada penelitian ini adalah siswa kelas IV SDN Jatipamor I sebagai pemakai produk. Adapun waktu penelitian dilakukan selama lima bulan dimulai sejak februari sampai uji coba produk bulan juni 2021.

Untuk mengumpulkan data terkait dengan bagaimana ke efektifitasan produk ini, peneliti menggunakan wawancara, angket dan dokumentasi. Sedangkan untuk menguji instrument kepada judgment expert peneliti menggunakan angket yang ditujukan kepada 2 ahli materi yang terdiri dari 1 dosen dan 1 guru, sedangkan ahli media terdiri dari 2 dosen Universitas Muhammadiyah Cirebon. Adapun kriteria penilaian instrumennya dapat dilihat pada tabel di bawah ini:

Tabel 1. Pedoman Skala Penilaian Instrumen Angket

\begin{tabular}{ll}
\hline Keterangan & Penilaian \\
\hline Sangat Baik (SB) & 5 \\
\hline Baik (B) & 4 \\
\hline Cukup (C) & 3 \\
\hline Kurang (K) & 2 \\
\hline Sangat Kurang (SK) & 1 \\
\hline
\end{tabular}

Sumber: Novianti (2015:4)

Hasil validasi yang sudah tertera dalam lembar validasi kemudian dianalisis dengan menggunakan rumus sebagai berikut:

$$
P=\frac{f}{N} x 100 \%
$$

Keterangan:

$\mathrm{P}=$ angka presentase data angket

$f=$ jumlah skor yang diperoleh

$N=$ jumlah skor maksimum (Herawati, 2016:32).

Hasil presentase kelayakan yang didapat kemudian diinterpretasikan ke dalam kategori berdasarkan tabel berikut:

Tabel 2. Kriteria Kelayakan

\begin{tabular}{ll}
\hline Penilaian & Kriteria \\
\hline $81 \leq \mathrm{P} \leq 100 \%$ & Sangat Layak \\
\hline $61 \leq \mathrm{P} \leq 80 \%$ & Layak \\
\hline $41 \leq \mathrm{P} \leq 60 \%$ & Cukup Layak \\
\hline $21 \leq \mathrm{P} \leq 40 \%$ & Tidak Layak \\
\hline $0 \leq \mathrm{P} \leq 20 \%$ & Sangat Tidak Layak \\
\hline
\end{tabular}

Berdasarkan tabel kriteria kelayakan media diatas, media interaktif berbasis ebook melalui pendekatan SAVI pada pembelajaran IPA kelas IV dikatakan layak secara teoritis apabila presentase kelayakan sebesar $\geq 61 \%$ dari seluruh unsur yang terdapat dalam angket penilaian validasi ahli materi dan ahli media (Novianti, 2015:4). 
Tahap potensi dan masalah

\section{HASIL DAN PEMBAHASAN}

Identifikasi masalah pada penelitian ini dilakukan dengan melakukan analisis kebutuhan di SDN Jatipamor 1, yaitu melalui wawancara kepada guru kelas IV dan beberapa orang siswa, Masalah mendasar yang terjadi pada siswa kelas IV berdasarkan hasil dari wawancara yang dilakukan oleh penulis adalah penggunaan media dalam pembelajaran IPA masih cenderung mengandalkan buku cetak sebagai media pembelajaran utamanya. Buku cetak yang digunakan oleh guru sebagai media pembelajaran hanya berisi uraian materi, beberapa ilustrasi gambar dan latihan soal dengan bentuk soal yang kurang bervariasi, sehingga media pembelajaran tersebut kurang menarik dan kurang dapat memberikan visualisasi terhadap konsep materi yang sifatnya abstrak, terlebih pada mata pelajaran IPA materi bentuk dan perubahan energi. Konsep materi tersebut bersifat abstrak sehingga siswa membutuhkan media pembelajaran yang dapat membantu memvisualisasikan materi tersebut agar mereka dapat memahami materi dengan lebih baik.

Kesulitan mempelajari konsep materi IPA dan kurangnya partisipatif aktif siswa juga seringkali ditemukan selama proses pembelajaran IPA, hal ini dikarenakan media pembelajaran yang digunakan belum bervariasi dan belum mampu memfasilitasi gaya belajar siswa yang beragam. Berdasarkan hasil wawancara dengan guru dan siswa, diketahui bahwa siswa kelas IV memiliki gaya belajar yang beragam, ada siswa yang lebih senang belajar hanya dengan mendengarkan guru berceramah, adapula siswa yang lebih senang dan lebih mudah memahami materi apabila menggunakan media gambar dan ikut terlibat dengan melakukan suatu kegiatan. Keberagaman ini apabila tidak terfasilitasi dengan baik akan berdampak pada penurunan keberhasilan belajar siswa, karena siswa yang gaya belajarnya tidak terfasilitasi cenderung cepat jenuh dan tidak tertarik untuk belajar.

Disisi lain, proses pembelajaran IPA pada masa pandemi ini dilaksanakan dengan sistem yang berubah-ubah menyesuaikan dengan frekuensi penyebaran pandemi covid-19. Kebijakan belajar tatap muka terbatas sudah mulai dilaksanakan di SDN Jatipamor I, namun kebijakan untuk belajar dirumah dengan sistem pembelajaran jarak jauh (online) juga sempat diterapkan kembali karena kenaikan jumlah penyebaran pandemi covid-19 di lokasi dekat sekolah. Sistem pelaksanaan pembelajaran yang berubah-ubah ini semakin membuat hadirnya media pembelajaran semakin diperlukan untuk memfasilitasi siswa belajar secara mandiri dimana saja, layaknya di sekolah. Namun, penggunaan media pembelajaran baik saat pembelajaran tatap muka maupun online masih kurang bervariatif dan belum memanfaatkan teknologi yang seharusnya diterapkan pada pendidikan masa kini secara maksimal. Adanya sarana proyektor atau LCD di sekolah dan ketidakasingan siswa dalam memanfaatkan perangkat elektronik seperti handphone mendukung adanya sebuah inovasi media pembelajaran yang dapat membantu siswa untuk belajar di kelas maupun ketika mengulas kembali materi yang sudah dipelajari di rumah.

\section{Tahap pengumpulan informasi}

Bentuk pengumpulan informasi dalam penelitian dan pengembangan ini berupa penelitian dan teori yang berkaitan dengan media pembelajaran berikut dengan cara pengoprasian dan pembuatan media pembelajaran yang dapat mengatasi potensi dan masalah yang ditemukan di sekolah. Informasi-informasi tersebut dikumpulkan dari beragam sumber seperti jurnal, buku, dan sumber internet. Hasil dari pengumpulan informasi ini menjadikan penulis mengembangkan produk berupa media interaktif berbasis ebook melalui pendekatan SAVI pada pembelajaran IPA kelas IV Sekolah Dasar, untuk membantu siswa kelas IV belajar dengan cara yang lebih menarik dan memungkinkan siswa untuk belajar dimana saja layaknya di sekolah.

\section{Tahap desain produk media interaktif berbasis ebook melalui pendekatan savi}

Proses pembuatan produk dimulai dengan mendesain lembaran-lembaran kertas ebook menggunakan website bookcreator. Posisi kertas dan halaman yang digunakan adalah landscape dengan rasio 4:3. Proses dimulai dengan mendesain background dan membuat cover, kemudian membuat daftar menu dan petunjuk penggunaan, memasukkan 
$\mathrm{KI}, \mathrm{KD}$ dan tujuan pembelajaran, lalu membuat peta konsep dan memasukkan materi pembelajaran dengan memperhatikan unsur-unsur pendekatan SAVI yaitu Somatic, Audio, Visual, dan Intelektual, serta memasukkan soal evaluasi, daftar pustaka dan profil penulis.

Pada ebook interaktif yang dibuat, unsur somatic diintegrasikan ke dalam bentuk aktivitas percobaan dan simulasi perubahan bentuk energi dari website laboratorium virtual PhET simulation. Unsur Auditory, diintegrasikan ke dalam bentuk aktifitas membaca dan mendengarkan, yang memungkinkan siswa melakukan kegiatan membaca sambil mendengarkan. Audio direkam dengan menggunakan fitur yang terdapat pada website bookcreator. Unsur Visual, diintegrasikan ke dalam bentuk komik pendidikan, gambar dan ilustrasi terkait materi. Gambar dan ilustrasi yang diintegrasikan ke dalam ebook bersumber dari internet. Selain itu, video pembelajaran juga diintegrasikan ke dalam ebook sehingga memungkinkan siswa untuk memahami materi secara audio visual. Video pembelajaran dan video tutorial percobaan sederhana yang diintergrasikan ke dalam ebook bersumber dari Youtube. Sementara unsur Intelektual, diintegrasikan ke dalam bentuk latihan soal dan uji pemahaman pada siswa. LKS yang diintegrasikan ke dalam ebook. LKS dibuat dengan bantuan website wizer.me.

\section{Tahap validasi desain media interaktif berbasis ebook melalui pendekatan savi}

Validasi desain dilakukan oleh ahli materi dan ahli media. Instrumen berupa angket validasi yang diberikan kepada validator untuk mengetahui respon ahli terhadap produk yang dikembangkan yang kemudian dijadikan dasar kelayakan dan revisi dari produk sehingga produk media interaktif berbasis ebook melalui pendekatan SAVI pada pembelajaran IPA kelas IV layak untuk diuji coba. Validasi materi dilakukan oleh dosen Universitas Muhammadiyah Cirebon yaitu Ibu Susilawati, M.Pd dan guru kelas IV SDN Jatipamor I yaitu Ibu Titi Rohaeti, S.Pd.SD. Hasil yang diperoleh data dilihat pada tabel di bawah ini:

Tabel 3. Hasil Validasi Ahli

\begin{tabular}{ll}
\hline $\begin{array}{l}\text { Aspek yang } \\
\text { dinilai }\end{array}$ & $\begin{array}{l}\text { Presentase } \\
(\%)\end{array}$ \\
\hline Isi Materi & $97 \%$ \\
\hline Bahasa & $87 \%$ \\
\hline Jumlah & $95 \%$ \\
\hline
\end{tabular}

Berdasarkan tabel di atas dapat diketahui bahwa aspek kelayakan isi materi yang terdiri atas 11 butir penilaian memperoleh presentase sebesar 97\%, sementara aspek kelayakan Bahasa yang terdiri atas tiga butir penilaian memperoleh presentase sebesar $87 \%$. Berdasarkan presentasi skor penilaian tersebut diperoleh rata-rata skor sebesar $95 \%$, sehingga media interaktif berbasis ebook melalui pendekatan SAVI pada pembelajaran IPA kelas IV Sekolah Dasar termasuk ke dalam kriteria "Sangat Layak" untuk diuji coba di lapangan. Hal tersebut juga diperkuat dengan penyataan ahli materi yang menyatakan bahwa produk ebook yang dikembangkan dapat digunakan sebagai media pembelajaran yang dapat membantu siswa dalam memahami materi pelajaran. Ebook yang dikembangkan juga sudah memenuhi beberapa kriteria aspek penilaian menurut Badan Standar Nasional Pendidikan dalam Fahrudiin, (2020:69) yaitu kesesuaian materi dengan KI, KD, dan tujuan pembelajaran, menyajikan contoh atau ilustrasi untuk memudahkan siswa memahami materi, menggunakan Bahasa yang sederhana dan mudah dipahami sesuai dengan tingkat kemampuan siswa, menggunakan kalimat yang tidak bermakna ganda dan menarik sehingga menumbuhkan minat siswa dalam membaca dan memahami materi.

Validasi media dilakukan oleh dosen Universitas Muhammadiyah Cirebon yaitu kepada Erna Labudasari, M.Pd dan Hanikah, M.Pd. Hasil yang diperoleh data dilihat pada tabel di bawah ini: 
Tabel 4. Hasil Validasi Ahli

\begin{tabular}{ll}
\hline Aspek yang dinilai & Presentase (\%) \\
\hline Tampilan & $94 \%$ \\
\hline Penggunaan & $90 \%$ \\
\hline Isi Media & $95 \%$ \\
\hline Jumlah & $\mathbf{9 4 \%}$ \\
\hline
\end{tabular}

Berdasarkan tabel di atas dapat diketahui bahwa aspek kelayakan tampilan yang terdiri atas 10 butir penilaian memperoleh presentase sebesar $94 \%$, aspek kelayakan penggunaan yang terdiri atas tiga butir penilaian memperoleh presentase $90 \%$, sementara aspek kelayakan isi media yang terdiri atas enam butir penilaian memperoleh presentase 95\%. Berdasarkan presentase skor penilaian diperoleh rata-rata skor sebesar 94\%, sehingga media interaktif berbasis ebook melalui pendekatan SAVI pada pembelajaran IPA kelas IV Sekolah Dasar termasuk ke dalam kriteria "Sangat Layak" untuk diuji coba di lapangan. Hal ini juga diperkuat dengan pernyataan ahli media yang menyatakan produk ebook yang dikembangkan dapat menarik perhatian siswa, meningkatkan antusiasme siswa saat pembelajaran berlangsung, dan mudah untuk digunakan. Ebook yang dikembangkan juga telah memenuhi beberapa kriteria aspek penilaian yang disebutkan oleh Winarno dalam Ernawati dan Sukardiyono (2017:205) yaitu kesesuaian isi materi dengan tujuan awal pembuatan media, adanya informasi tambahan seperti petunjuk penggunaan, kemenarikan tampilan ebook, adanya navigasi/petunjuk arah, penggunaan ebook yang menyenangkan dan interaktif, kemudahan dalam mengakses, dan adanya evaluasi serta umpan balik.

\section{Tahap revisi desain media interaktif berbasis ebook melalui pendekatan savi}

Hasil presentase penilaian menunjukkan bahwa ebook yang dikembangkan sangat layak untuk diuji coba, namun terdapat beberapa saran dari validator, diantaranya disarankan untuk mengganti warna background dan teks yang digunakan pada produk agar terlihat lebih menarik, memperbesar ukuran huruf agar terlihat lebih jelas, menyederhanakan kata-kata petunjuk pengerjaan LKS, serta memberi halaman pada daftar menu. Berikut adalah revisi produk berdasarkan komentar dan saran ahli media dan ahli materi:

a. Ahli Materi I

Berdasarkan lembar instrumen validasi yang telah diberikan penulis kepada ahli materi I yaitu Ibu Susilawati, M.Pd diperoleh hasil bahwa materi yang terdapat pada media sudah baik dan tidak perlu adanya revisi.

b. Ahli Materi II

Berdasarkan lembar instrumen validasi yang telah diberikan penulis kepada ahli materi II yaitu Ibu Titi Rohaeti, S.Pd.SD diperoleh hasil bahwa materi yang terdapat pada media sudah baik dan tidak perlu adanya revisi.

\section{c. Media I}

Berdasarkan lembar instrumen validasi yang telah diberikan penulis kepada ahli media I yaitu Ibu Erna Labudasari, M.Pd diperoleh hasil agar dapat dilakukan revisi pada warna background dan teks yang digunakan pada produk 


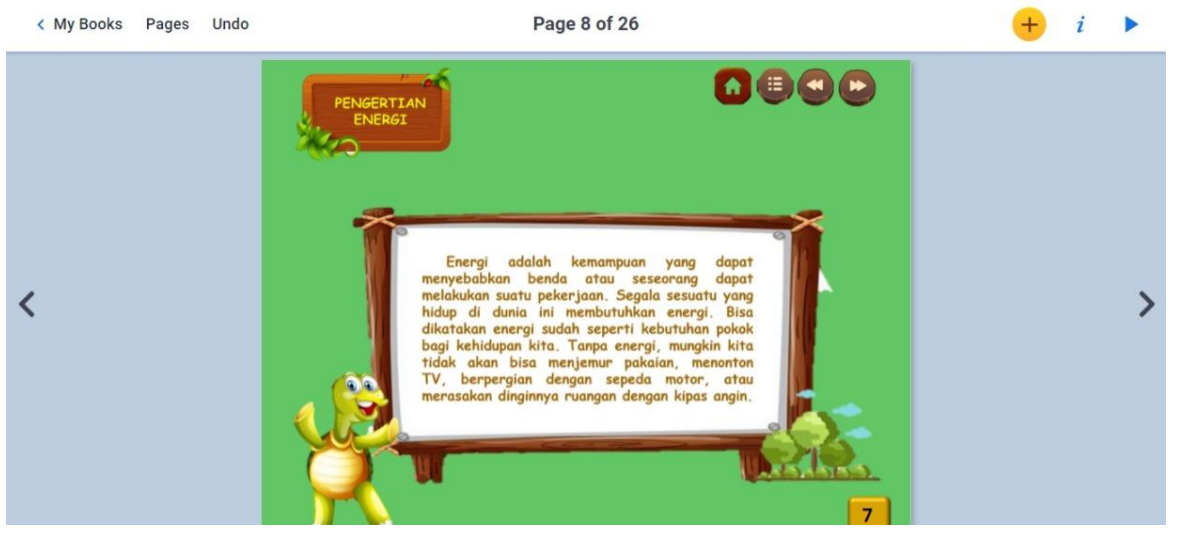

Gambar 1 Tampilan Warna Background dan Teks Sebelum Revisi

< My Books Pages Undo Page 8 of 26

$+i \triangleright$

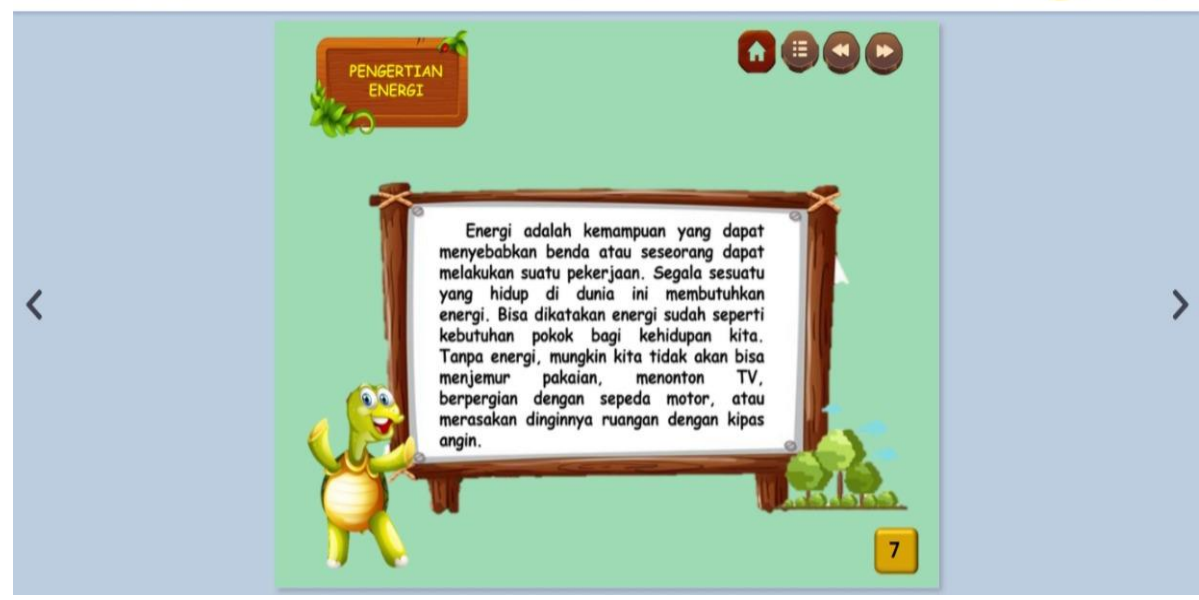

Gambar 2 Tampilan Warna Background dan Teks Setelah Revisi

Tahap Uji Coba Produk media interaktif berbasis ebook melalui pendekatan savi

Responden dalam uji coba kelompok kecil ini berjumlah sembilan siswa kelas IV SDN Jatipamor I yang mewakili tingkat kemampuan tinggi, sedang dan rendah. Respon siswa terhadap aspek tampilan yang terdiri atas lima butir penilaian memperoleh presentase sebesar $94 \%$, aspek materi yang terdiri atas satu butir penilaian memperoleh jumlah presentase $100 \%$, aspek penggunaan yang terdiri atas tiga butir penilaian memperoleh presentase $96 \%$, aspek kebutuhan yang terdiri atas dua butir pernilaian memperoleh presentase sebesar 99\%, dan aspek Bahasa yang terdiri atas satu butir penilaian memperoleh presentase sebesar $100 \%$. Berdasarkan presentase skor penilaian tersebut diperoleh rata-rata skor sebesar $96 \%$. Sesuai dengan hasil presentase penilaian tersebut dapat dinyatakan bahwa produk ebook yang dikembangan termasuk ke dalam kriteria "Sangat Layak" untuk digunakan sebagai media pembelajaran IPA. Hal ini juga diperkuat dengan pernyataan siswa yang menyatakan bahwa belajar menggunakan produk ebook yang dikembangkan penulis sangatlah menyenangkan, materi yang dipelajari menjadi lebih mudah untuk dipahami, dan ebook mudah untuk dioperasikan.

Sebagai media pembelajaran produk ini memiliki kelebihan pada beberapa aspek. Pertama, pada aspek penggunaan, produk ini dapat digunakan sebagai salah satu alternatif media pembelajaran baik saat pembelajaran tatap muka maupun pembelajaran jarak jauh (online). Selain itu, produk juga dapat memberikan pengalaman dan wawasan pengatahuan baru kepada siswa, baik dari segi materi IPA maupun penggunaan teknologi dalam pembelajaran. Produk ini juga dapat diakses diperangkat elektronik manapun dan kapanpun selama terhubung dengan jaringan internet dan web browser tanpa perlu menginstal aplikasi tambahan untuk membuka produk karena produk ini berformat HTML, dan karena produk ini 
sudah pada tahap publish internet, sehingga semua bisa mengakses produk selagi mereka memiliki link untuk mengakses produk.

Kedua, produk memiliki kelebihan pada aspek tampilan, yaitu penyajian ebook yang dilengkapi oleh beragam konten seperti komik pendidikan, video pembelajaran yang menarik, simulasi percobaan, video percobaan sederhana dan tutorial percobaannya, dapat membantu siswa belajar dengan cara yang lebih bervariasi menyesuaikan gaya belajar mereka dan tidak jenuh saat pembelajaran berlangsung. Selain itu, materi yang disajikan dalam produk diilustrasikan dengan hal-hal yang berhubungan dalam realita kehidupan sehari-hari siswa, sehingga pembelajaran dapat lebih bermakna bagi siswa. Namun, sebagai media pembelajaran produk ini juga memiliki kelemahan yaitu ebook baru bisa diakses jika terhubung dengan jaringan internet, tetapi kelemahan ini bisa diatasi dengan mendownload materi secara terpisah dari ebook misalnya mendownload video pembelajaran yang ada pada ebook, hal ini bisa dilakukan karena video pembelajaran tersebut terhubung langsung dengan youtube maka ketika perangkat sedang terhubung dengan jaringan internet video tersebut bisa didownload terlebih dahulu, dengan begitu video tersebut dapat diakses kembali meskipun offline.

\section{SIMPULAN}

Berdasarkan hasil penelitian dapat disimpulkan bahwa secara konseptual pengembangan media pembelajaran bagi memberikan pemahaman yang lebih baik dalam mempelajari konsep pembelajaran IPA. Penggunaan media dalam pembelajaran mampu meningkatkan keaktifan siswa dan membuat siswa menjadi lebih tertarik, termotivasi untuk menguasai materi dan lebih percaya diri untuk mengikuti proses pembelajaran. Selain itu, penilaian dari validator ahli materi terhadap media yang dikembangkan menunjukkan hasil dengan kriteria sangat layak. Hal ini ditunjukkan dengan presentase kalayakan sebesar $95 \%$. Penilaian dari validator media juga menunjukkan hasil yang positif dan kriteria kelayakan yang sangat layak, dengan presentase nilai sebesar 94\%. Respon siswa terhadap produk juga sangat baik dan masuk dalam kriteria sangat layak, dilihat dari hasil penilaian uji coba kelompok kecil yang memperoleh presentase nilai sebesar $96 \%$. Dari hasil penilaian tersebut dapat disimpulkan bahwa media interaktif berbasis ebook melalui pendekatan SAVI pada pembelajaran IPA kelas IV sangat layak untuk digunakan sebagai media dalam pembelajaran IPA.

\section{DAFTAR PUSTAKA}

Anggraini, D. R. 2018. "Pengembangan E-Modul Materi Energi Dan Perubahannya Dengan Pendekatan SAINTIFIK Kelas IV SD/MI." Skripsi FTIK Universitas Islam Negeri Raden Intan Lampung: tidak diterbitkan.

Batubara, H. .. 2020. Media Pembelajaran Efektif. Semarang: Fatawa Publishing.

Budiyanto, A. 2013. "Penerapan Pendekatan Somatic Auditory Visual Intelegency (SAVI) Dengan Media Audio Visual Untuk Meningkatkan Kualitas Pembelajaran PKn Pada Siswa Kelas IVA SDN Hj. Isriati Baiturrahman 1 Semarang." Skripsi FIP Universitas Negeri Semarang: tidak diterbitkan.

Ernawati, I. dan Sukardiyono, T. 2017. "Uji Kelayakan Media Pembelajaan Interaktif Pada Mata Pelajaran Administrasi Server." Elinvo (Electronic, Informatics, and Vocational Education) 2(2):204-10.

Fahrudiin, I. 2020. “Analisis Buku Ajar Sejarah Kebudayaan Islam Menurut Badan Standar Nasional Pendidikan." At-Tarbawi: Jurnal Kajian Kependidikan Islam 5(2):65-82.

Faiz, Aiman. 2021. "PERAN FILSAFAT PROGRESIVISME DALAM MENGEMBANGKAN KEMAMPUAN CALON PENDIDIK DI ABAD-21." Jurnal Education and Development Institut Pendidikan Tapanuli Selatan 9(1):131-35.

Faiz, Aiman, Purwati Purwati, and Imas Kurniawaty. 2020. "Construction of Prosocial Empathy Values Through Project Based Learning Methods Based on Social Experiments (Study of Discovering Cultural Themes in the Sumber-Cirebon Society)." Ta Dib : Jurnal Pendidikan Islam 9(1):51-62.

Faiz, Aiman, Bukhori Soleh, Imas Kurniawaty, and Purwati. 2021. "Tinjauan Analisis Kritis 
Terhadap Faktor Penghambat Pendidikan Karakter Di Indonesia." Jurnal Basicedu Volume 5(4):1766-77.

Herawati. 2016. "Pengembangan Modul Keanekaragaman Aves Sebagai Sumber Belajar Biologi." Jurnal Lentera Pendidikan LPPM UM METRO 1(1):28-36.

Istiqomah, N. dan Kusuma, A. .. 2019. "Pembelajaran Blended Learning Matematika Di Era Generasi Alpha." Prosiding Sendika 5(1):595-600.

Jannah, N., Fadiawati, N., dan Tania, L. 2017. "Pengembangan Ebook Interaktif Berbasis Fenomena Kehidupan Sehari-Hari Tentang Pemisahan Campuran." Jurnal Pendidikan Dan Pembelajaran 6(1):186-98.

Lukitawati, P. 2014. "Pengembangan Media Pembelajaran Matematika Berbasis ICT (Information And Comunication Technology) Melalui Pendekatan SAVI (Somatic, Auditory, Visual, and Intellectual) Pada Materi Geometri Transformasi Kelas VII Di SMP Ma'had Islam Pekalongan." Delta 2(2):42-50.

Madang, K. Santoso, L.M. dan Pasela, W. .. 2017. "Pengembangan Pendekatan Somatik, Auditori, Visual, Dan Intelektual (SAVI) Berbantuan Media Animasi Terhadap Hasil Belajar Peserta Didik." Didaktika Biologi: Jurnal Penelitian Pendidikan Biologi 1(1):7178.

Nefrita. 2019. "Implementation Of PHET Learning Media In Efforts To Improve Activities And Physics Learning Outcome Of Students In Class XI SMA 4 Pekanbaru." Geliga Sains $7(1): 46-54$.

Novianti, D. .. 2015. "Pengembangan Modul Akuntansi Aves Tetap Berbasis Pendekatan Saintifik Sebagai Pendukung Implementasi K-13 Di SMKN 2 Buduran." Jurnal Pendidikan 3(1):1-9.

Putri, G.H., Panjaitan, R.L., dan Sujana, A. 2017. "Penerapan Pendekatan SAVI Untuk Meningkatkan Hasil Belajar Siswa Pada Materi Gaya Mempengaruhi Gerak Dan Bentuk Benda." Jurnal Pena IImiah 2(1):361-70.

Sugiyono. 2015. Metode Penelitian Pendidikan (Pendekatan Kuantitatif, Kualitatif, Dan R\&D). Bandung: Alfabeta.

Suryani, W. dan Sukarmin. 2012. "Pengembangan E-Book Interaktif Pada Materi Pokok Elektrokimia Kelas XII SMA." Unesa Journal of Chemica Education 1(2):54-62.

Syafitri, D. .. 2020. "Pengembangan Aplikasi E-Book Kesan Koba Kebudayaan Dan Kekhasan Kota Batu Sebagai Media Pembelajaran Tema 1 Subtema 1 Kelas IV." Skripsi FKIP Universitas Muhammadiyah Malang: tidak diterbitkan.

Wedyawati, N. dan Lisa, Y. 2019. Pembelajaran IPA Di Sekolah Dasar. Yogyakarta: Deepublish.

Yaumi, M. 2018. Media Dan Teknologi Pembelajaran. Jakarta: Prenadamedia Group.

Yogiswara, S. .. 2019. "Pengembangan Modul Berbasis E-Book Menggunakan Aplikasi Kvisoft Flipbook Maker Untuk Meningkatkan Minat Dan Hasil Belajar Kognitif Peserta Didik SMA." Skripsi FMIPA Univeristas Negeri Yogyakarta: tidak diterbitkan. 